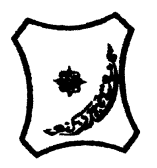

Bayero Journal of Pure and Applied Sciences, 10(1): 516 - 524

ISSN 2006 - 6996

\title{
ASSESSMENT OF MACROINVERTEBRATE SPECIES DIVERSITY, WATER STATUS AND IMPACT OF DEVELOPMENT ON THE KANO RIVER SYSTEM
}

\author{
${ }^{*}$ Suleiman, K. ${ }^{1}$ and Abdullahi, I.L. ${ }^{2}$ \\ *1Department of Biological Sciences College of Arts, Science and Remedial Studies Kano. \\ ${ }^{2}$ Department of Biological Sciences, Bayero University Kano. \\ ${ }^{*}$ Correspondence author: kbsuleiman@yahoo.com
}

\begin{abstract}
A study of the impact of developmental activities on the distribution and biodiversity of aquatic macroinvertebrates of Kano River was conducted between June 2014 to May 2016. Six sampling sites from the upstream receiving point to downstream were selected along the river. Result indicated that the species richness were 2271 and 2844 in first twelve months and preceding respectively, grouped into 19 families and classified into five functional feeding groups. Chironomidae was found to be the dominant family in the study accounting for $24 \%$ abundance and $18 \%$ abundance in wet and dry seasons of 2014-2015 and 2015-2016 respectively. Communities were most diverse at Site $C(0.94)$ in 2014-2015. Site A was the least evenly distributed in the first Twelve month as indicated by the lowest index $(0.50)$. However high evenness was observed in Site $C(0.99)$. Sites species composition in degrees of association using Pearson Product Moment Correlation (PPMC) revealed site $A$ and $F$ showed high correlation of (.968) while the lowest value was between site $F$ and $D(.622)$. However, in 2015-2016 site $E$ and $F$ showed high correlation of (.995) while moderate correlation was between Site $E$ and $A$ (.611). Results were discussed, concluded and recommendations were made.
\end{abstract}

Key words: Assessment, Development, Diversity, Impact, Kano River, Macroinvertebrates

\section{INTRODUCTION}

Tiga Dam is a zoned filled earth dam located on River Kano with the Longitude $8^{\circ} 40^{\circ}$ and Latitude $11^{\circ} 15^{\prime}$, it is $47.2 \mathrm{~m}$ high above the sea level and $7.24 \mathrm{~km}$ long, it has a water storage capacity of 1974million cubic liters of water (HJRBDA, 2014). The water is to be use to irrigate over 180,000 ha of land in the Kano River Basin under Kano River Project (KRIP) (HJRBDA 2007). The Tiga Dam is one of the largest dam in Nigeria and was designed and built between 1970 and 1975. After almost Thirty Three years of operations of the Kano River Irrigation Projects, source of drinking water for Kano Metropolis as well as other towns and villages along the river course within the riparian, Fishing and recreational activities and currently the construction of Hydroelectric power plant at the Dam outlet. It is useful to identify and assess some of the changes in the river status on the environment especially on the inhabiting macroinvertebrates community (Alexander et al., 2016). However, in 2013, the state government under Alhaji Rabiu Musa Kwankwaso commissioned Indian Electrical Company Skipper Electricals International Limited (SEIL) to Construct Hydroelectric power plant with the capacity of generating 10 Mega Watts of electricity at the outlet valve chamber of Tiga Dam a continuous part of Kano River, with aim at improving the supply of electricity to the local community and to some areas in urban Kano. The development has great potential for future development for the following reasons: first, it will accelerate economic prosperity in the undeveloped area; second, it can solve the difficulty in using electricity for local people; third, it can also make profits for investors. Hydropower as renewable energy resource plays an important role in improving ecological condition of the river and protecting the environment (IMARES, 2012).

Although construction of Hydroelectric power plant has brought in great economic interests for people, it has also caused some environmental problems, such as downstream drought by the dams, deterioration of vegetation and soil and water loss which consequently impoverished the inhabiting macroinvertebrates communities ( $\mathrm{Fu}$ et al., 2008). It has been reported that dams with Hydropower projects impede the flux of water (Hauer et al., 2017 ), sediments (Kerry et al., 2017), biological community (Ning et al., 2017), and can strongly alter the aquatic faunal composition and structure as well as the general water quality of the river from the upstream to the downstream (Helena et al., 2017).

At present, research on the impact of Hydroelectric power plants on the river ecosystem has been mainly concentrated on fish mortality and river status, were several reports indicated its safety on the fish faunal community during and after construction periods (IMARES, 2012). 
However, studies on aquatic macroinvertebrates community of the river during and after construction research is very rare. Therefore in this study the choice of macroinvertebrates as indicators of biological status of the Kano River was inform by their special attributes as; macroinvertebrates are often the taxa group of choice for biological status assessment of river environments ( Cid et al., 2016; Tinaotenda et al., 2016) as they are found throughout the length of the river (Shishani et al., 2014), have limited mobility and a relatively long lifespan (Christos et al., 2017). Most interestingly, freshwater macroinvertebrate species vary in their sensitivity to disturbance (Pedro et al., 2017) and, as a result, their presence or absence can be used to make assessment about the ongoing activity from the headwaters down the river (Hauer et al., 2017) and make inferences about the river status. Although Seasonal changes in macroinvertebrate taxon abundances can be related to their life history, temporal variation into macroinvertebrate community structure can potentially affect the status assessment (Elisabeth et al., 2017). A number of studies have described distinctive macroinvertebrate assemblages in the reaches below dams (Ivan 2012), and some have inferred that changes in substrate characteristics drive the resulting assemblages (Alexander et al., 2016). Construction of Hydroelectric power plant come with some changes in the river ecosystem and disturbances may lead to the highest level of biodiversity (Claudio et al., 2015). The alteration of the variability by disturbances can also help to predict upcoming changes in ecosystem dynamics (Steve et al., 2016). Changes in community structure include; a modification of the total abundance of individuals within a location, a modification of the total number of species, a change in the variance to mean abundance ratio for particular species, or a change in the identities of species present in the assemblage (Ning et al., 2017). Many rivers world over are adversely impacted by urbanization, deforestation, construction, irrigation, drainage of wetlands and pollution (Fornaroli et al., 2016).

The study is aimed at revealing changes in the structure of macroinvertebrates along the Kano River water from Tiga Dam outlet where Hydroelectric power plant is being constructed to the confluence point with Challawa River water and also to provide information about annual abundance, diversity and species composition. Thus, carrying out such studies will significantly provide useful insight for river ecologist; river basin management agencies, identify sensitive and resilient species as well as their significance to water management, biodiversity protection and conservation.

\section{MATERIALS AND METHODS}

\section{Study Area}

Kano state is located between latitude $10^{\circ} 30^{\prime}$ to $12^{\circ} 40^{\circ} \mathrm{N}$ and longitude $7^{\circ} 40^{\prime}$ and $9^{\circ} 30^{\prime} \mathrm{E}$. The climate is classified as tropical dry and wet type. Kano River is located on the Southern part of Kano between the latitude $10^{\circ} 10^{\prime}$ to $11^{\circ}$ $50^{\prime} \mathrm{N}$ and longitude $8^{\circ} 17$ and $8^{\circ} 40^{\prime} \mathrm{E}$ (Olofin, 1985). Kano River confluence with Challawa River at Tamburawa Bridge and is about fiftyeight kilometers $(58.8 \mathrm{~km})$ in length from Tiga dam discharge outlet (Suleiman and Abdullahi, 2016). It flows southeast to north meandering to north east at confluence (Figure 1).

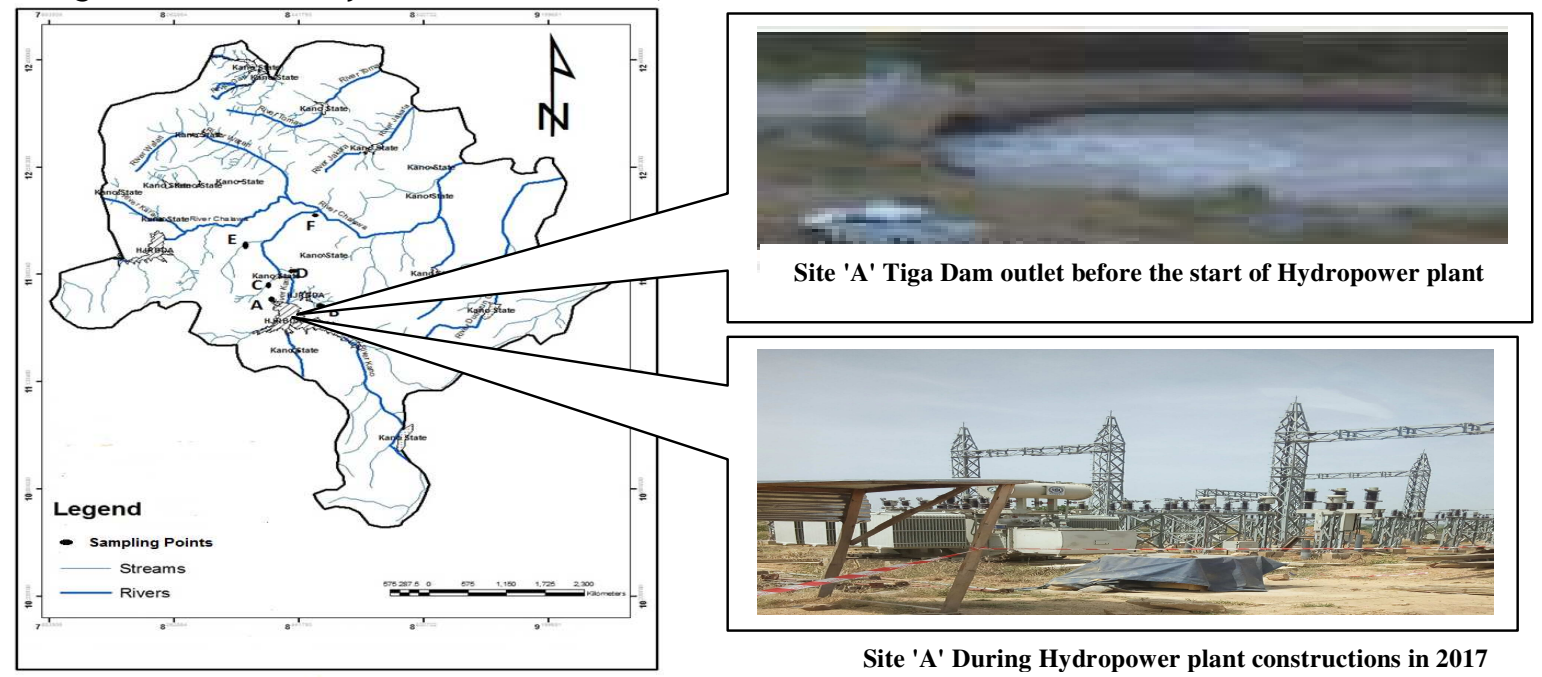

Source: Carto. Geography Department, BUK 2014

Fig. 1: Map of the study area showing sampling points and the construction Area 
Sites were selected spatially using a randomized systematic procedure described by Olsen and Peck (2008) and USEPA (2012). Sites were delineated as $A, B, C, D, E$ and $F$ along the river streams from the Hydroelectric power plant construction area (Site A) down to the confluence point water intake station (Site F).

\section{Sample collection}

The macroinvertebrates were sampled in three sampling occasion monthly from June 2014 to May 2016 using the standardized kick-net method as described in Gabriels et al. (2010) Macroinvertebrates sampling protocol was based on Stark et al., (2001), and their count from sampling sites was on the rule of Barbour et al., (1999), Mereta et al., (2013), and Helson and Williams (2013). The samples were fixed in the field with $40 \%$ formalin and taken to Bayero University Kano laboratory in individual sites labeled plastic containers. In the laboratory, the samples were washed, sorted, and all individuals were identified mostly to family with the aid of taxonomic keys of Mugnai et al. (2010). Sampling was conducted in early morning hours along the river reaches in triplicate each month, ranges for physical variables determined and recorded at the sampling sites.
Water Temperature $\left({ }^{\circ} \mathrm{C}\right)$ was measured in situ using thermometer as described by APHA, (2012) and $\mathrm{pH}$ was determined using dip-inn mobile battery operated $\mathrm{pH}$ meter, as described by Maiti (2004). Dissolved Oxygen $(\mathrm{mg} / \mathrm{L})$ was determine using 200 model DO meter as described by Maiti (2004). Electrical Conductivity $(\mu S)$ was measured using Jenway conductivity meter model 4010. Alkalinity $(\mathrm{mg} / \mathrm{L})$ was determined from the $250 \mathrm{ml}$ of river water sample following titrimetric method of Maiti (2004). Total Nitrate (TN) and Total Phosphate (TP) were determined using multiparameter ion specific meter (HANNA C2000 model) as described by HANNA Instruction Manual. Five days incubation method was employed to determine the Biochemical Oxygen Demand (BOD) level of the water samples as described by Okafor (1985) and Maiti (2004).

\section{Data Analysis}

The analytical procedures were that, identified taxon count from selected sites for Twenty Four (24) months constituting first sampling year 2014-2015 and 2015-2016 for the second year were recorded as well as physical and chemical parameters. Macroinvertebrate diversity was calculated using biodiversity indices of the Hill's Family (Azevêdo et al., 2015).

Where, $\mathrm{D}$ is measurement of different macroinvertebrates present

$\Sigma$ is the summation,

In (Lin) Natural Log

$\mathrm{pi}$ is the proportion of individuals found in species $\left(\mathrm{n}_{\mathrm{i}}\right) /$ total number of individual in a community $(\mathrm{N})$,

$\mathrm{N}$ is the number of species or species richness,

$\mathrm{H}_{\max }$ is the maximum diversity possible,

$E$ is the Evenness,

$S_{j}$ is the Jaccard Similarity coefficient and usually multiply by $100 \%$,

$\mathrm{S}_{\mathrm{a}}$ and $\mathrm{S}_{\mathrm{b}}$ are the numbers of species unique to samples $\mathrm{a}$ and $\mathrm{b}$,

$\mathrm{S}_{\mathrm{b}}$ is the number of species unique to the first sample

$\mathrm{S}_{\mathrm{c}}$ is the number of species common to $\mathrm{a}$ and $\mathrm{b}$.

Correlations between sampling sites were conducted to ascertain the level of associations between sites organisms composition using Pearson Product Moment correlation (PPMC) (Mukaka 2012 )

All data analyses were carried out using IBM-JAVA SPSS version 21 (2012).

\section{RESULTS and DISCUSSION}

We measured a range of variables to evaluate the Physico-chemical stream environment (Table 1). Fluctuations of the measured Physico-chemical and biological community were observed. Increasing temperature affect macroinvertebrates community structure (Wotton, 1995). Temperature ranged from $16.30^{\circ} \mathrm{C}$ to $36.30^{\circ} \mathrm{C}$ throughout the sampling period, the differences were due to prevailing ambient temperature and season (Wang et al., 2013). However, the high Alkalinity value of $7.50 \mathrm{ml} / \mathrm{L}$ was reported at site $\mathrm{F}$ and this may be due to the force of the river water according to Stefen et al., (2016), often refer to as "Hydrodynamics". Dissolved Oxygen (DO) of the water has recorded the highest value of 8.9 $\mathrm{ml} / \mathrm{L}$ at site $\mathrm{D}$ in the month of March 2016. 
The values of Total Nitrate and Total Phosphate recorded in the study was highest in the site $F$, these were particularly of lower concentrations at site $\mathrm{B}$ and $\mathrm{C}$ throughout the sampling months. Yangdong (2017), concluded that macroinvertebrate functional feeding groups (Collectors) are indicative of Phosphate and Nitrate enrichment in the river water.

Table 2, present the composition of the stream to the total of 2271 and 2844 macroinvertebrates sampled and grouped into 19 families (Nikolaos et al., 2017). Differences were also observed in term of river macroinvertebrates across the sites. Higher macroinvertebrates were sampled in dry season of the two year sampling periods. However, higher count (1938) was in recorded in 20152016 dry season period. This could be due to halt of the construction activities in the transition periods from the state governments. Chironomidae was the most abundant family succeeded by Nemouridae and Simuliidae in total of 550-477, 253-266, and 223-253 respectively. This corroborates the findings of Boggero, et al. (2006) and Al-Shami, et al. (2010). However, systematic increase were observed in lowest families are Planariidae, Oligochaeta and Agriidae 11-30, 63-67, and 3438 respectively. Different macroinvertebrates composition could be due to site different physical habitat characteristics, the key determinants influencing the structure and composition of aquatic assemblages (Yildiz 2014; Alexander, et al. 2016). Yujun et al., (2017), emphasizes that habitat quality has a significant impact on the species "presenceabsence" and species richness which is the determining factor for the abundance and distribution of aquatic organisms.

Macroinvertebrate diversity was calculated using biodiversity indices of the Hill's Family (Azevêdo et al., 2015) (Table 4). Site E had the highest density of taxa while site $D$ had the lowest in 2014/15. The macroinvertebrate community was most species diverse at Site $C$ followed by $D$ in the preceding year. Site $A$ was the least evenly distributed in the first Twelve month as indicated by the lowest index (0.50), however high evenness was observed in Site C, the result corroborate similar findings from the work of Alexander et al., (2016). Jaccard similarity index showed similarities between all sampling sites during the twenty four months excerpt site A with the lowest value of 0.60 and was the site where constructions works - the Kano Hydroelectricity is taking place. This corroborates the report of Douglas et al., (2017) that, the disturbed sites has the lesser similarity index value. Family Chironomidae have the highest representation in dry and wet season which correspond with the findings of Annie et al., (2014), that abundance of tolerant taxa such as Chironomidae increases with increasing disturbance. Macroinvertebrates based on the distribution among sites were correlated in pair wise to ascertain the degree of association (Mukaka 2012) since equal sampling efforts were employed at all site (Eva et al., 2016) (Table 5 and 6). All correlations between sites macroinvertebrates composition revealed significant high positive correlation (Minar et al., 2016). In 2014-2015 site $A$ and $F$ showed .968 while the lowest value was between site $F$ and D (.622). However, in 2015-2016 site E and $F$ showed .995 while low value was observed in Site $E$ and $A$ (.611) according to Guilford Rule of Thumb (Alexander et al., 2016) . Five Functional Feeding Groups were identified based on the feeding mechanisms by which macroinvertebrates obtain their food resources (Merrits et al., 2008), these include filtering collectors, scrapers, shredders, predators and gathering collectors (Table 3 ). Disturbance due to pollution are important determinant of macroinvertebrates distribution according to Pedro et al., 2017.

Table 1: Mean Physico-chemical variables of the River water 2014-2016

\begin{tabular}{|c|c|c|c|c|c|c|c|c|c|c|}
\hline \multirow[b]{2}{*}{ Parameter } & \multicolumn{5}{|c|}{$2014-2015$} & \multicolumn{5}{|c|}{$2015-2016$} \\
\hline & Mean & $\begin{array}{c}\text { Std. } \\
\text { Deviation }\end{array}$ & $\begin{array}{l}\text { Std. } \\
\text { Error }\end{array}$ & Min & $\operatorname{Max}$ & Mean & $\begin{array}{c}\text { Std. } \\
\text { Deviation }\end{array}$ & $\begin{array}{l}\text { Std. } \\
\text { Error }\end{array}$ & Min & Max \\
\hline Temp & 26.3167 & \pm 5.24630 & 0.61828 & 16.3 & 36.3 & 25.3167 & \pm 5.23543 & 0.56734 & 16.3 & 34.3 \\
\hline $\mathrm{pH}$ & 6.9847 & \pm .58998 & 0.06953 & 5.3 & 8.3 & 7.0235 & \pm .67921 & 0.14596 & 6.1 & 8.2 \\
\hline Cond & 80.5306 & \pm 22.3581 & 2.63493 & 46.3 & 155.7 & 80.5306 & \pm 22.3581 & 2.6349 & 52.3 & 135.7 \\
\hline Alkal & 3.3458 & \pm .67988 & 0.08012 & 1.8 & 5 & 3.5681 & \pm .69111 & 0.12045 & 1.64 & 5.3 \\
\hline DO & 5.4528 & \pm 1.50782 & 0.1777 & 2.7 & 9.8 & 6.2211 & \pm 1.96700 & 0.1787 & 2.44 & 9.01 \\
\hline $\mathrm{TN}$ & 2.4042 & \pm 1.05663 & 0.12452 & 0.7 & 4.9 & 2.44 & \pm 3.00 & 2.44 & 1.2 & 4.9 \\
\hline TP & 3.1389 & \pm .79675 & 0.0939 & 1.6 & 5 & 3.6432 & \pm .85672 & 0.23451 & 1.7 & 5.2 \\
\hline $\mathrm{BOD}_{5}$ & 1.4847 & \pm .54866 & 0.06466 & 0.7 & 3.4 & 1.7632 & \pm .65489 & 0.06733 & 0.8 & 4.4 \\
\hline
\end{tabular}

Min- Minimum: Max- Maximum : Std - Standard 
Table 2: Species distribution across the sites of the study area from June 2014 - May 2016

\begin{tabular}{|c|c|c|c|c|c|c|c|c|c|c|c|c|c|c|}
\hline \multirow[b]{3}{*}{ Taxon } & \multicolumn{7}{|c|}{$2014-2015$} & \multicolumn{7}{|c|}{$2015-2016$} \\
\hline & \multirow[b]{2}{*}{ A } & \multirow[b]{2}{*}{ B } & \multicolumn{3}{|c|}{ Sites } & \multirow[b]{2}{*}{$F$} & \multirow[b]{2}{*}{$\begin{array}{c}\text { Tota } \\
1\end{array}$} & \multirow[b]{2}{*}{ A } & \multirow[b]{2}{*}{ B } & \multirow[b]{2}{*}{ C } & \multicolumn{2}{|c|}{ Sites } & \multirow[b]{2}{*}{$F$} & \multirow[b]{2}{*}{$\begin{array}{c}\text { Tota } \\
1\end{array}$} \\
\hline & & & C & D & $\mathrm{E}$ & & & & & & D & $\mathrm{E}$ & & \\
\hline Simuliidae & 57 & 31 & 35 & 16 & 47 & 37 & 223 & 29 & 46 & 49 & 47 & 32 & 50 & 253 \\
\hline Hydrophilidae & 39 & 24 & 34 & 15 & 12 & 31 & 155 & 42 & 45 & 19 & 43 & 31 & 36 & 216 \\
\hline Batidae & 10 & 14 & 25 & 2 & 13 & 12 & 76 & 25 & 16 & 46 & 21 & 18 & 26 & 152 \\
\hline Hydrobidae & 15 & 6 & 11 & 24 & 11 & 32 & 99 & 30 & 37 & 30 & 39 & 23 & 50 & 209 \\
\hline Gammaridae & 7 & 1 & 5 & 6 & 17 & 2 & 38 & 10 & 9 & 9 & 8 & 15 & 14 & 65 \\
\hline Vivaltidae & 9 & 13 & 1 & 10 & 5 & 11 & 49 & 15 & 22 & 24 & 12 & 38 & 14 & 125 \\
\hline Hirudidae & 2 & 4 & 11 & 2 & 16 & 30 & 65 & 15 & 14 & 14 & 13 & 18 & 14 & 88 \\
\hline $\begin{array}{l}\text { Platycnemidida } \\
e\end{array}$ & 38 & 19 & 31 & 16 & 24 & 14 & 142 & 23 & 33 & 24 & 26 & 41 & 23 & 170 \\
\hline Aphelocheiridae & 9 & 17 & 19 & 15 & 8 & 18 & 86 & 20 & 21 & 22 & 17 & 22 & 23 & 125 \\
\hline Nemouridae & 48 & 50 & 35 & 36 & 27 & 57 & 253 & 43 & 48 & 26 & 51 & 40 & 58 & 266 \\
\hline Corixidae & 13 & 2 & 12 & 19 & 23 & 11 & 80 & 18 & 11 & 23 & 16 & 32 & 20 & 120 \\
\hline Agriidae & 5 & 5 & 4 & 5 & 4 & 11 & 34 & 12 & 9 & 17 & 9 & 7 & 19 & 73 \\
\hline Oligochaeta & 0 & 8 & 27 & 8 & 5 & 15 & 63 & 11 & 12 & 10 & 9 & 8 & 17 & 67 \\
\hline Planariidae & 0 & 2 & 0 & 2 & 5 & 2 & 11 & 2 & 5 & 6 & 7 & 7 & 3 & 30 \\
\hline Chironomidae & 71 & 101 & 52 & 98 & 132 & 96 & 550 & 86 & 68 & 91 & 79 & 110 & 43 & 477 \\
\hline Hydroptilidae & 7 & 13 & 2 & 0 & 0 & 4 & 26 & 12 & 15 & 4 & 11 & 7 & 11 & 60 \\
\hline Siplonuridae & 44 & 35 & 19 & 18 & 26 & 15 & 157 & 25 & 38 & 14 & 34 & 23 & 30 & 164 \\
\hline Hydrometridae & 28 & 22 & 35 & 29 & 15 & 16 & 145 & 22 & 17 & 19 & 33 & 22 & 23 & 136 \\
\hline Lymbricoidae & 1 & 5 & 5 & 8 & 0 & 0 & 19 & 6 & 9 & 6 & 8 & 8 & 11 & 48 \\
\hline Total & $\begin{array}{c}40 \\
3\end{array}$ & $\begin{array}{c}37 \\
2\end{array}$ & $\begin{array}{c}36 \\
3\end{array}$ & $\begin{array}{c}32 \\
9\end{array}$ & 390 & 414 & 2271 & 446 & 475 & 453 & 483 & 502 & 485 & 2844 \\
\hline
\end{tabular}

Table 3: Distribution of macroinvertebrates groups in wet and dry season

\begin{tabular}{|c|c|c|c|c|c|c|c|c|c|}
\hline \multirow[b]{3}{*}{ Taxon } & \multirow[b]{3}{*}{$\begin{array}{l}\text { Functional group } \\
\text { (Feeding) }\end{array}$} & \multicolumn{4}{|c|}{$2014-2015$} & \multicolumn{4}{|c|}{$2015-2016$} \\
\hline & & \multicolumn{2}{|c|}{ Wet } & \multicolumn{2}{|c|}{ Dry } & \multicolumn{2}{|c|}{ Wet } & \multicolumn{2}{|c|}{ Dry } \\
\hline & & Total & $\begin{array}{l}\% \\
\text { Freq. }\end{array}$ & Total & $\begin{array}{l}\% \\
\text { Freq. }\end{array}$ & Total & $\begin{array}{l}\% \\
\text { Freq. }\end{array}$ & Total & $\begin{array}{l}\% \\
\text { Freq. }\end{array}$ \\
\hline Simuliidae & Filtering collector & 63 & 9 & 171 & 11 & 71 & 8 & 182 & 9 \\
\hline Hydrophilidae & Scrapers & 44 & 6 & 117 & 8 & 60 & 7 & 154 & 8 \\
\hline Batidae & Scrapers & 26 & 3 & 45 & 3 & 42 & 5 & 112 & 6 \\
\hline Hydrobidae & Scrapers & 55 & 7 & 44 & 2 & 68 & 9 & 141 & 7 \\
\hline Gammaridae & Filtering collector & 23 & 3 & 14 & 1 & 32 & 3 & 30 & 2 \\
\hline Vivaltidae & Shredders & 22 & 3 & 27 & 2 & 43 & 5 & 82 & 4 \\
\hline Hirudidae & Predators & 32 & 4 & 32 & 2 & 43 & 5 & 41 & 2 \\
\hline Platycnemididae & Predators & 40 & 5 & 112 & 7 & 45 & 5 & 124 & 6 \\
\hline Aphelocheiridae & Predators & 23 & 3 & 59 & 4 & 46 & 5 & 76 & 3 \\
\hline Nemouridae & Shredders & 76 & 10 & 177 & 11 & 84 & 10 & 185 & 10 \\
\hline Corixidae & Scrapers & 15 & 2 & 64 & 4 & 33 & 3 & 81 & 4 \\
\hline Agriidae & Predators & 31 & 4 & 0 & 0 & 37 & 4 & 33 & 2 \\
\hline Oligochaeta & Filtering collector & 11 & 2 & 27 & 2 & 18 & 2 & 49 & 3 \\
\hline Planariidae & Shredders & 3 & 1 & 8 & 1 & 10 & 1 & 18 & 1 \\
\hline Chironomidae & Gathering collector & 181 & 24 & 374 & 24 & 148 & 16 & 341 & 18 \\
\hline Hydroptilidae & Scrapers & 2 & 1 & 24 & 2 & 17 & 1 & 34 & 2 \\
\hline Siplonuridae & Scrapers & 46 & 6 & 116 & 8 & 50 & 5 & 128 & 6 \\
\hline Hydrometridae & Predators & 34 & 5 & 115 & 7 & 38 & 4 & 100 & 5 \\
\hline Lymbricoidae & Gathering collector & 15 & 2 & 4 & 1 & 21 & 2 & 27 & 2 \\
\hline Total & & 743 & 100 & 1528 & 100 & 906 & 100 & 1938 & 100 \\
\hline
\end{tabular}


Table 4 : Density and Diversity of macroinvertebrates in the sampling sites

\begin{tabular}{|c|c|c|c|c|c|c|c|c|c|c|c|c|}
\hline \multirow[b]{3}{*}{ Indices } & \multicolumn{6}{|c|}{ 2014-2015 } & \multicolumn{6}{|c|}{$2015-2016$} \\
\hline & \multirow[b]{2}{*}{ A } & \multirow[b]{2}{*}{ B } & \multicolumn{2}{|c|}{ Sites } & \multirow[b]{2}{*}{$E$} & \multirow[b]{2}{*}{$F$} & \multicolumn{6}{|c|}{ Sites } \\
\hline & & & C & D & & & A & B & C & D & $E$ & $F$ \\
\hline Density & 403 & 372 & 363 & 329 & 390 & 414 & 446 & 475 & 453 & 483 & 502 & 485 \\
\hline $\begin{array}{c}\text { Shannon - } \\
\text { Weiner }\end{array}$ & 0.41 & 0.81 & 0.94 & 0.70 & 0.80 & $\begin{array}{c}0.7 \\
8\end{array}$ & 0.89 & 0.81 & 0.69 & 0.64 & $\begin{array}{c}0 . .7 \\
2\end{array}$ & 0.84 \\
\hline $\begin{array}{c}\text { Species } \\
\text { evenness }\end{array}$ & 0.50 & 1.24 & 0.99 & 0.90 & 0.70 & $\begin{array}{c}0.9 \\
2\end{array}$ & 0.87 & 0.67 & 0.63 & 0.62 & 0.68 & 0.82 \\
\hline $\begin{array}{c}\text { Jaccard } \\
\text { Similarity }\end{array}$ & 0.60 & 0.96 & 0.94 & 0.93 & 0.96 & $\begin{array}{c}0.9 \\
0 \\
\end{array}$ & 0.73 & 0.90 & 0.89 & 0.93 & 0.91 & 0.90 \\
\hline \multicolumn{7}{|c|}{ Table 5: R } & \multicolumn{4}{|c|}{5 based on PPMC 2014-2015 } & & \\
\hline & Site A & & Site B & & Site C & & Site D & & Site E & & Site I & \\
\hline Site A & 1 & & & & & & & & & & & \\
\hline Site B & $.858^{\mathrm{m*}}$ & & 1 & & & & & & & & & \\
\hline Site C & $.819^{\mathrm{m*}}$ & & $.770^{\circ}$ & & 1 & & & & & & & \\
\hline Site D & $.743^{\mathrm{m*}}$ & & $.909^{\prime \prime \prime}$ & & $.702^{x *}$ & & 1 & & & & & \\
\hline Site $\mathrm{E}$ & $.872^{\mathrm{mm}}$ & & $.893^{m *}$ & & $.686^{2 \pi}$ & & $.909 "$ & & 1 & & & \\
\hline Site $F$ & $.968^{\mathrm{mom}}$ & & $.889^{m}$ & & .746 * & & $.622^{* \prime}$ & & $.859^{\mathrm{nm}}$ & & 1 & \\
\hline
\end{tabular}

.90 to $1.00(-.90$ Very high positive (negative)

to -1.0$)$ correlation

.70 to $.90(-.70$ High positive (negative)

to -.90$)$ correlation

.50 to .70 ( -50 to Moderate positive (negative)

-.70) correlation

Table 6: Relationship between sampling sites based on PPMC 2015-2016

\begin{tabular}{ccccccc}
\hline & Site A & Site B & Site C & Site D & Site E & Site F \\
\hline Site A & 1 & & & & & \\
Site B & $.974^{* * *}$ & 1 & & & & \\
Site C & $.683^{* * *}$ & $.810^{* * *}$ & 1 & & & \\
Site D & $.831^{* * *}$ & $.922^{* * *}$ & $.602^{* * *}$ & 1 & & \\
Site E & $.611^{* * *}$ & $.897^{* * *}$ & $.762^{* * *}$ & $.899^{* * *}$ & 1 & \\
Site F & $.931^{* * *}$ & $.877^{* * *}$ & $.924^{* *}$ & $.929^{* *}$ & $.995^{* *}$ & 1 \\
\hline
\end{tabular}

.90 to $1.00(-.90$ Very high positive (negative)

to -1.0$)$ correlation

.70 to $.90(-.70$ High positive (negative)

to -.90$)$ correlation

.50 to .70 ( -50 to Moderate positive (negative)

$-.70)$ correlation

\section{CONCLUSION}

The impacts of development activities and other land use on the Kano river water, biodiversity, and distribution of benthic macroinvertebrates were clear. The results showed that construction activities have impacts on some aspect of the river ecosystem particularly site ' $A$ ' - Tiga dam outlet. On the physical factors of the rivers, construction of the Hydro turbine channel makes river habitats fragmentary. However the impact of electrochemical factors were not obvious, hence the work is ongoing. There were significant differences in the variation pattern in the Physico-chemical parameters between sampling months. As for the variation of macroinvertebrates, species composition, abundance, dominant taxa and functional groups were all more or less disturbed at the span of Twenty Four months. However, species abundance of Chironomidae across the sites revealed there is a disturbance event in the upstream.

\section{Recommendation}

Preliminary activities in Hydroelectric power plant constructions and installations should include documentation on river physical habitat, water quality and Community biota. 
Toxicity study of the hydropower turbine on the river macroinvertebrates community should be carried out to detect changes in their conditions in the post construction period. Abundance of Chironomidae, Nemouridae and Simuliidae in the Kano river through its' diversity should be use as indicators of

\section{REFERENCES}

Alexander, M., Milnera, B., Andrea, W., Jerome, E., Freilichd, R., and Blacke, R. (2016). Detecting significant change in stream benthic macroinvertebrate communities in wilderness areas. Ecological Indicators, 60: 524-537.

Al-Shami, S.A., Rawi, C.S.M., Hassan Ahmad, A., and Nor, S.A.M., (2010). Distribution of Chironomidae (Insecta: Diptera) in polluted rivers of the Juru River Basin, Penang, Malaysia. Jour. Environ. SciChina, 22, 1718-1727.

Annie, S., Dominique, G. and Philippe, A. (2014). Effect of Disturbance Regime on Alpha and Beta Diversity of Rock Pools, Diversity, 6, 1-17.

APHA. (2012). Standard methods for the examination of water and wastewater. 18th Edition. American Public Health Association, Washington, DC. Modified March 06, 2012.

Azevêdo, D.J.S., Barbosa, J.E.L ., Gomes, W.I.A., C, D.E. Porto, D.E., Marques, J.C. and Molozzi, J. (2015). Diversity measures in macroinvertebrate and zooplankton communities related to the trophic status of subtropical reservoirs: Contradictory or complementary responses? Ecological Indicators, 50: 135-14.9

Barbour, M.T., Gerritsen, J., Snyder, B.D., Stribling, J.B., (1999). Rapid Bioassessment Protocols for use in Streams and Wadeable Rivers: Periphyton, Benthic Macroinvertebrates, and Fish, second ed. U.S. Environmental Protection Agency, Office of Water, Washinton, DC.

Boggero, A. L., Fureder, V., Lencioni, T. Simcic, B. Thaler, U. Ferrarese, A. F. Lotter and Ettinger, R. (2006). Littoral chironomid communities of alpine lakes in relation to environmental factors. Hydrobiologia 562: 145-165.

Christos, T., Aikaterini, V., Anastasios, S., Peter, R., and Nikolaos, S. (2017). Response of freshwater macroinvertebrates to rainfall-induced high flows: A hydro ecological approach, Ecological Indicators, 73:432-442.

Cid, N., Verkaik, I., García-Roger, E. M., Rieradevall, M., Bonada N., SánchezMontoya, M. M., Gómez, R., Suárez, M. L., Vidal-Abarca, M. R., Demartini, D., Buffagni, A., Erba, S., Karaouzas, I., ecological condition of the river community. Biotic community changes in the Kano River should be regularly monitored for use in policy framework by the river managers on water resource use, human activities, biodiversity and conservation.

Skoulikidis, N. and Prat, N. (2016). A biological tool to assess flow connectivity in reference temporary streams from the Mediterranean Basin, Science of the Total Environment, 540: 178-190.

Claudio, D., Monteiro J., Leandro, J., and Neusa, H. (2015). Analysis of urban impacts on aquatic habitats in the central Amazon basin: Adult odonates as bioindicators of environmental quality. Ecol. Indct., 48, 303-311.

Douglas, B., M. and Kenneth, H. R. (2017). A Bayesian network assessment of macroinvertebrate responses to nutrients and other factors in streams of the Eastern Corn Belt Plains, Ohio, USA, Ecological Modeling ,345: 21-29.

Elisabeth, B., Peter, H., Mathias, K., Moritz, L., Ralf, B., and Andrea, S. (2017). Water quality variables and pollution sources shaping stream macroinvertebrate communities, Science of the Total Environment, 564: 324-356.

Eva, C., Serrano, B., Corinne, G., Laure, B., Ma, A., and Armienta, H. (2016). Potential application of macroinvertebrates indices in bioassessment of Mexican streams, Ecological Indicators 61: 558-567.

Fornaroli, R., Cabrini, S., Zaupa, R., Bettinetti, C. and Boggero, A. (2016). Quantile regression analysis as a predictive tool for lake macroinvertebrate biodiversity. Ecological Indicators, 61: 728-738.

Fu, X., Tang, T., Jiang, W., Li, F., Wu, N., Zhou, S. and Cai, Q. (2008). Impacts of small hydropower plants on macroinvertebrate communities, Acta Ecologica Sinica, Vol. 28 (2): 45-52.

Gabriels, W., Lock, K., De Pauw, N. and Goethals, P.L.M., (2010). Multimetric Macroinvertebrate Index Flanders (MMIF) for biological assessment of rivers and lakes in Flanders (Belgium). Limnologica 40 (3): 199-207.

George, G. N., Ayub M. N., Nathan, N. G. and Wamicha, W. N. (2004). Impact of water quality on macroinvertebrate assemblages along a tropical stream in Kenya. African Journal of Ecology, 42, 208-216

Hadejia-Jamaare River Basin Development Authority (HJRBDA) (2007). Federal Government of Nigeria, Federal Ministry of Agriculture and Water Resources, Department of Dams and reservoir Operations, Compendium of Nigerians 
Dams -Briefs, Statistics and Purpose, p175.

Hadejia-Jamaare River Basin Development Authority (HJRBDA) (2014). Water For Development . A Biannual news letter of the Hadejia-Jamaare River Basin Development Authority, pp 8 - 10.

Hauer, C. P. Holzapfel P. Leitner and W. Graf (2017). Longitudinal assessment of hydropeaking impacts on various scales foran improved process understanding and the design of nmitigation measures, Science of the Total Environment, 575: 1503-1514.

Helena, V., Tiago, V., Alexandra, B., Pieter, G., and João Carlos, M. (2017). Comparison of thermodynamic-oriented indicators and trait-based indices ability to track environmental changes: Response of benthic macroinvertebrates to management in a temperate estuary, Ecological Indicators ,73: 809-824

Helson, J.E., and Williams, D.D., (2013). Development of a macroinvertebrate multimetric index for the assessment of low-land streams in the neotropics. Ecol. Indic. 29,167-78.

IBM SSPSS (2012). IBM- JAVA SUPPORT SPSS VERSION 21 Statistic Software License. IBM Corporation Virginia, USA.

Institute for Marine Resources and Ecosystem Studies (IMARES) (2012). Fish Flow Innovations Pentair Fairbanks, Nijhuis Parallelweg 47102 DE Winterswijk, Dissel 41671 NG Medemblik pp 5-14.

Ivan Skála (2012). Distribution of macroinvertebrates in relation to the quantity and quality of organic matter in streams in the western Czech Republic, Jour. of Ecohydrology and Hydrobiology, Vol. 12 (3), 199-209.

Kerry, M., Tristan, M., Childress, C. and Heaton, R. (2017). Sediment source identification and load prediction in a mixed-use Piedmont watershed, South Carolina, Journal of Environmental Management 185: 60-69.

Maiti, S. K. (2004). Handbook of Methods in Environmental Studies. Vol. I Water and Wastewater Analysis, ABD Publishers, Raj, India, Pp 242- 258

Mereta, S.T., Boets, P., De Meester, L., Goethals, P.L.M., (2013). Development of a multimetric index based on benthic macroinvertebrates for the assessment of natural wetlands in Southwest Ethiopia. Ecological Indicators. 29, 510-521.

Merrit, R.W., Cummins, K.W. and Berg, M. B., (2008). An Introduction to the Aquatic Insects of North America, fourth ed. Kendall/Hunt Publishing, Dubuque, lowa, pp. 1158.

Minar, N., Koen, L., Pieter, B., Gert, E., Thi Hanh, T., Marie, A., Peace, L. Natalija, S.,
Elina, B., Dries, L., Luis. D., Peter, L.M.G. (2016). Ecological water quality analysis of the Guayas river basin (Ecuador)based on macroinvertebrates indices, Limnologica, 57: 27-59.

Moya, N., Tomanova, S., and Oberdorff, T. (2007). Initial development of a multimetric index based on aquatic macroinvertebrates to assess streams condition in the Upper Isiboro-Secure Basin, Bolivian Amazon. Hydrobiologia , 589, 107-116.

Mugnai, R., Nessimian, J. and Baptista, D. (2010). Manual de identificac, ão de macroinver-tebrados aquáticos do Estado do Rio de Janeiro. Technical Books Editora, Rio deJaneiro, Brazil.

Mukaka, M. M. (2012). Statistics Corner: A guide to appropriate use of Correlation coefficient in medical research Malawi Medical Journal, 24(3): 69-71.

Nikolaos, A., Cédric, B., Nicolas, D. and Fred, J. (2017). Building functional groups of marine benthic macroinvertebrates on the basis of general community assembly mechanisms, Journal of Sea Research 121: $59-70$.

Ning, D., Weifang, Y., Yunlei, Z., Ivan, G., Jie, Z., Kai, C., Nicolas, V., Erik, J., Zhengwen, L., and Beixin, W. (2017). Different responses of functional traits and diversity of stream macroinvertebrates to environmental and spatial factors in the Xishuangbanna watershed of the upper Mekong River Basin, China, Science of the Total Environment, 574: 288-299.

Okafor, N. (1985). Aquatic and waste Water Microbiology, Fourth Dimension Publishing Company Ltd Enugu, Nigeria. pp 115-119.

Olofin. E.A. (1985): Human resources to the natural environment in Kano region. $2^{\text {nd }}$ inter Confr. History of Kano. Proceedings $16^{\text {th }}-20^{\text {th }}$ Sept. 1985.

Olsen, A.R. and Peck, D.V. (2008). Survey design and extent estimates for the Wadeable Streams Assessment. J. N. Am. Benthol. Soc., 27: 822-836.

Pedro, A., Helena, V., Antónia, S., John, H., Angel, B., João, C.,Marquesa, J. and Magalhães, N. (2017). Do structural and functional attributes show concordant responses to disturbance? Evidence from rocky shore macroinvertebrate communities, Ecological Indicators, 75: 57-72.

Shishani, M., Victor, K. and Richard, K. (2014). River Health Assessment Using Macroinvertebrates and Water Quality Parameters: A case of the Orange River in Namibia, Physics and Chemistry of the Earth, 76-78: 140-148. 
Stark, J. D., Boothroyd, I. K. G., Harding, J. S., Maxted, J. R. and Scarsbrook, M. R. (2001), Protocols for sampling macroinvertebrates in wadeable streams. New Zealand Macroinvertebrates Working Group Report No. 1 ISSN 1175-7701.

Stefan, S., Philippa, B., Jonathan, D. T., Denise, F. and Peter, H. (2016). Scale-dependent effects of river habitat quality on benthic invertebrate communities- Implications for stream restoration practice. Science of the Total Environment 553: 495-503.

Steve J., Martyn. K., Tim, A. Mary, K., and Don, M. (2016). A Water Framework Directivecompatible metric for assessing acidification in UK and Irish rivers using diatoms, Science of the Total Environment 493: 155-172.

Suleiman, K. and Abdullahi, I. L. (2016). Multivariate Approach to the Study of Aquatic Species Diversity of Dendrite Streams of River Kano, Nigeria, Bajopas, Vol. 9 (2):

Tinotenda, M, Taurai, B. and Tongayi, M. (2016). Choice of biota in stream assessment and monitoring programs in tropical streams: A comparison of diatoms, macroinvertebrates and fish. Ecological Indicators, 63: 128-143.

USEPA, (2012). Stream flow In Water: Monitoring and Assessment. United States
Environmental Protection Agency (USEPA), Washington, DC, United States.

Wang, Y., Peng, W., Yujun, B., Zaixing, T., Jingwen, L., Xue,S., Laura, F., and Mustavich, L. (2013). Assessment of surface water quality via multivariate statistical techniques: A case study of the Songhua River Harbin region, China. Journal of Hydro-environment Research 7: $30-40$.

Wotton, R. S. (1995). Temperature and Lakeoutlet Communities. J. Therm. Biol. Vol. 20, No. 1/2, 121-125.

Yangdong, P., Guiping, D., Lizhu, W., Yong, C. Wanting, P. Wange, L., Baxing, W., Jie, Z. and Ronglin, X. (2017). Effects of in situ phosphorus enrichment on the benthos in a subalpinekarst stream and implications for bioassessment in nature reserves, Ecological Indicators 73: 274283.

Yildiz, I. and Ali, F. (2014). Biological diversity and seasonal variation of mesozooplankton in the southeastern Black Sea coastal ecosystem, Turkish Journal of Zoology, 38: 179-190.

Yujun, Y., Xi, C., Zhifeng, Y., Silke, W., Shanghong, Z., and Yingjie, W. (2017). Evaluating the Ecological influence of Hydraulic Projects: A review of aquatic habitat suitability models, Renewable and Sustainable Energy Reviews, 68: 748-762 